\title{
Pseudopapillary and Solid Tumor of Pancreas (PPSTP): Report of Seven Cases
}

\author{
Pr Salah Berkane \\ University Abderahmane Mira. Bejaia \\ Corresponding Author: Pr Salah Berkane; salahberkane07@yahoo.fr
}

Received 17 February 2020;

Accepted 11 March 2020;

Published 31 March 2020

\section{Summary:}

Introduction: Described for the first time by Frantz in $1959^{[1]}$, pseudopapillary solid tumors of the pancreas (PPSTP) and have been defined since 1996 by the WHO as solids and papillaries ${ }^{[2]}$. They are particular by their clear predominance occurring in young women $(30$ years on average) and their good long-term prognosis ${ }^{[3]}$. Their positive diagnosis is often based on modern morphological examinations such as computed tomography and MRI. Surgery occupies a prominent place in their therapeutic management and all importance must be given to their diagnosis or at least their strong presumption in order to make curative surgical resection. We report seven cases all involve women, with an average age of 26.4 years (15-59 years). Radical surgery was performed in all cases with simple consequences in 5 patients and complicated in 2 others, including a pancreatic fistula and a pulmonary embolism. The histological study confirmed the diagnosis in all cases and the latter was supplemented by immunohistochemistry. In the long term, the seven patients are alive without recurrence at 100, 88, 78, 78, 74, 48 and 24 months. Conclusion: this form of pancreatic tumors has a good prognostic if well treated. The surgery is the best treatment. Clinician, radiologist, histologist and surgeon must know this disease.

Keywords: pseudopapillary tumor of pancreas - pancreatic tumor - favorable prognosis

\section{Introduction}

Described for the first time by Frantz in $1959^{[1]}$, pseudopapillary solid tumors of the pancreas (PPSTP) and have been defined since 1996 by the WHO as solids and papillaries ${ }^{[2]}$. They are particular by their clear predominance occurring in young women (30 years on average) and their good long-term prognosis ${ }^{[3]}$. Their positive diagnosis is often based on modern morphological examinations such as computed tomography and MRI. Surgery occupies a prominent place in their therapeutic management and all importance must be given to their diagnosis or at least their strong presumption in order to make curative surgical resection. The aim of the work is to report our experience on seven cases of pseudopapillary and solid tumor of pancreas (PPSTP) and followed in our service.

\section{Casuistic}

These are seven women with an average age of 26.4 years $(15,16$, $31,34,36,37$ and 59 years). Two patients underwent a cholecystectomy two years and ten years previously. Another patient had her tumor diagnosed just after vaginal delivery and a second had two desired pregnancies with the diagnosis of tumor already made. Clinically, all of these patients were in good general condition. Atypical pain was noted in three patients, a palpable mass in three, vomiting in two others, and asthenia in the latter. For two patients, the discovery of the tumor was fortuitous. Biologically, amylasemia and lipaemia were normal in second case and first case respectively. The rate of Ca19.9 was high in one patient and normal for the rest. The rate of CEA was normal for all patients (Table $\mathrm{n}^{\circ} 1$ : characteristics of the patients). Morphological exploration by transcutaneous ultrasound showed for the fourth patients where it was performed a formation with a heterogeneous echostructure very limited. The computed tomography was in favor of a hypodense tumor, provided with a capsule and taking the product of contrast. MRI performed in two patients objectified tissue formation taking contrast and cystic appearance in a third. One patient underwent endosonography and the latter showed very limited echogenic formation with necrotic center. A patient benefited from a cytoponction whose cytological study returned in favor of a carcinoma and the diagnosis retained was an adenocarcinoma of the head of the pancreas. For two patients, the diagnosis of PPSTP was made or mentioned before the surgery while in the five others the diagnoses mentioned were in favor of a benign tumor of the pancreas (mucinous tumors), endocrine or a stromal tumor. The tumor process was located in the head in two patients and in the left pancreas in five others. The tumor diameter was on average $105 \mathrm{~mm}(70-150 \mathrm{~mm})$ (Table $\mathrm{n}^{\circ} 2$ : Radiological aspects). The intraoperative exploration showed in the 6patients a formation with smooth and regular surface (encapsulated tumor), with soft to firm consistency and well limited. A corporeo-caudal tumor with $150 \mathrm{~mm}$ in large diameter (the largest in this series) showed adhesion to the left mesocolon. Two Whipple procedure, 
two left splenopancteatecomy, including one enlarged to the colon and three pancreatectomies and left without splenectomy were performed (Table ${ }^{\circ} 3$ : Intraoperative aspects). The operative suites were simple in five patients. One patient presented a dried up pancreatic fistula under medical treatment after 15 days and another presented a pulmonary embolism treated with anticoagulants for six months. The histological study was in favor of PPSTP in seven patients. These tumors had a capsule in all cases. These capsules, intact in five patients, were ruptured in two others. In the latter two patients, infiltration of the pancreas adjacent to the tumor was demonstrated. Histologically, papillary

Table $\mathrm{n}^{\circ}$ 1: Clinical and biological data.

\begin{tabular}{|c|c|c|c|c|c|c|c|}
\hline Variable & Cas 1 & Cas 2 & Cas 3 & Cas 4 & Cas 5 & Cas 6 & Cas 7 \\
\hline Age & 31 & 36 & 15 & 16 & 34 & 59 & 37 \\
\hline Sex & $\mathrm{F}$ & $\mathrm{F}$ & $\mathrm{F}$ & $\mathrm{F}$ & $\mathrm{F}$ & $\mathrm{F}$ & $\mathrm{F}$ \\
\hline Antecedent & $\begin{array}{l}1 \text { Synchronous } \\
\text { pregnancy }\end{array}$ & CX & NR & NR & $\begin{array}{l}2 \text { synchronous } \\
\text { pregnancy }\end{array}$ & Diabetes & $\mathrm{CX}$ \\
\hline Condition & Well & Well & Well & Well & Well & Well & Well \\
\hline Pain & No & Yes & Yes & No & No & Yes & No \\
\hline Palpable mass & No & No & Epigastrium & $\begin{array}{l}\text { Left hypo- } \\
\text { chondrium }\end{array}$ & No & $\begin{array}{l}\text { Left Hypo- } \\
\text { chondrium }\end{array}$ & No \\
\hline Asthenia & Yes & No & No & No & No & No & No \\
\hline Vomiting & Yes & No & No & Yes & No & No & No \\
\hline Fortuitous discovery & No & No & No & No & Yes & No & Yes \\
\hline Tumor site & $\begin{array}{l}\text { Corporeal and } \\
\text { caudal }\end{array}$ & Tail & Head & Body & Head & $\begin{array}{l}\text { Corporeal and } \\
\text { caudal }\end{array}$ & $\begin{array}{l}\text { Corporeal and } \\
\text { caudal }\end{array}$ \\
\hline Amylasemia & Normal & - & - & Normal & - & - & - \\
\hline Lipasemia & Normal & - & - & - & Normal & - & - \\
\hline Ca 19.9 & Normal & Normal & Normal & Normal & Normal & High & Normal \\
\hline CEA & Normal & Normal & Normal & Normal & Normal & Normal & Normal \\
\hline
\end{tabular}

CX: Cholecystectomy

Ca 19.9: Carbohydrate antigen 19.9

CEA: Carcino-embryonic antigen

NR: Nothing to Report

Table $\mathbf{n}^{\circ}$ 2: Radiological aspects.

\begin{tabular}{|c|c|c|c|c|c|c|c|}
\hline Exam & Case & Dimensions & Aspect & Capsule & $\begin{array}{l}\text { Contrast } \\
\text { enhancement }\end{array}$ & Limits & Preoperative diagnosis \\
\hline US & $\begin{array}{l}1 \\
2 \\
3 \\
4 \\
5 \\
6 \\
7\end{array}$ & $\begin{array}{l}40 \times 23 \\
\text { NM } \\
94 \times 80 \\
107 \times 87 \\
110 \times 78 \\
- \\
-\end{array}$ & $\begin{array}{l}\text { Heterogeneous } \\
\text { NM } \\
\text { Heterogeneous } \\
\text { Heterogeneous } \\
\text { Heterogeneous } \\
\text { NM } \\
\text { NM }\end{array}$ & $\begin{array}{l}\text { Yes } \\
\text { NM } \\
\text { NS } \\
\text { Yes } \\
\text { NS } \\
\text { NM } \\
\text { NM }\end{array}$ & $\begin{array}{l}- \\
- \\
- \\
- \\
- \\
- \\
-\end{array}$ & $\begin{array}{l}\text { NetNM } \\
\text { Net } \\
\text { Net } \\
\text { Net } \\
\text { NM } \\
\text { NM }\end{array}$ & $\begin{array}{l}\text { Pancreatic tumor } \\
- \\
\text { Hepatic tumor } \\
\text { Mixed tumor } \\
\text { Mixed tumor } \\
- \\
-\end{array}$ \\
\hline $\begin{array}{l}\text { CT } \\
\text { Scan }\end{array}$ & $\begin{array}{l}1 \\
2 \\
3 \\
4 \\
5 \\
6 \\
7\end{array}$ & $\begin{array}{l}42 \times 27 \\
78 \times 70 \\
112 \times 106 \\
101 \times 91 \\
120 \times 95 \\
70 \times 60 \\
65 \times 62\end{array}$ & $\begin{array}{l}\text { Hypodense } \\
\text { Hypodense } \\
\text { Hypodense } \\
\text { Hypodense } \\
\text { Hypodense } \\
\text { Hypodense } \\
\text { Hypodense }\end{array}$ & $\begin{array}{l}\text { Yes } \\
\text { Yes } \\
\text { Yes } \\
\text { Yes } \\
\text { Yes } \\
\text { Yes } \\
\text { Yes }\end{array}$ & $\begin{array}{l}\text { Yes } \\
\text { Yes } \\
\text { Yes } \\
\text { Yes } \\
\text { Yes } \\
\text { Ye } \\
\text { Yes }\end{array}$ & $\begin{array}{l}\text { Net } \\
\text { Net } \\
\text { Net } \\
\text { Net } \\
\text { Net } \\
\text { Net } \\
\text { Net }\end{array}$ & $\begin{array}{l}\text { Benign Tumor } \\
\text { Benign tumor } \\
\text { PPSTP } \\
\text { Tumor not specified } \\
\text { PPSTP } \\
\text { Mucinous cystadenoma } \\
\text { PPSTP ou neuroendocrine tumor }\end{array}$ \\
\hline MRI & $\begin{array}{l}1 \\
2 \\
3 \\
4 \\
5 \\
6 \\
7\end{array}$ & $\begin{array}{l}100 \times 90 \\
120 \times 105\end{array}$ & $\begin{array}{l}\text { NM } \\
\text { NM } \\
\text { NM } \\
\text { NM } \\
\text { Tissue T1 } \\
\text { Kystique }\end{array}$ & $\begin{array}{l}\text { NM } \\
\text { NM } \\
\text { NM } \\
\text { NM } \\
\text { Yes } \\
\text { Yes }\end{array}$ & $\begin{array}{l}\text { NM } \\
\text { NM } \\
\text { NM } \\
\text { NM } \\
\text { Yes } \\
\text { Yes }\end{array}$ & $\begin{array}{l}\text { NM } \\
\text { NM } \\
\text { NM } \\
\text { NM } \\
\text { Net } \\
\text { Net }\end{array}$ & $\begin{array}{l}\text { NM } \\
\text { NM } \\
\text { NM } \\
\text { NM } \\
\text { Stromal tumor } \\
\text { Mucinous or serous tumor }\end{array}$ \\
\hline EUS & 4 & & Necrotic center tumor & NS & - & - & NS \\
\hline FNA & 3 & Carcinoma & & & & & \\
\hline
\end{tabular}

or pseudopapillary architecture was also present in all cases. The cells are round; the nuclei have little pronounced abnormalities and rare to absent mitosis. No perineural sheathing or vascular emboli were noted (concept specified in 5cases). No lymph node (Table ${ }^{\circ} 4$ : Histological aspects.). An immunohistological study was carried out, confirming the diagnosis made using standard histology (Table $\mathrm{n}^{\circ} 5$ : immunohistochemical aspects). In the long term, the seven patients are alive without recurrence at $100,88,78$, $78,74,48$ and 26months. infiltration was noted (Lymph nodes analyzed in three cases) 
US: Transcutaneous ultrasound - CT scan: Computed tomography scan- MRI: magnetic resonance imaging - EUS: Endoscopic ultrasound PPSTP: pseudopapillary and solid tumor of pancreas. NM: Not made- NS: not specified- FNA: fine needle aspiration

Table $\mathbf{n}^{\circ}$ 3: Peroperative aspects, gestures et operating suites

\begin{tabular}{|c|c|c|c|c|c|c|}
\hline Case & Dimensions cm & Surface & Limits & Gesture & Immediat follow-up & Long-term follow-up \\
\hline 1 & 7 & Smoth & $\begin{array}{l}\text { Soft tumor and } \\
\text { well-limited }\end{array}$ & LP & Uneventfull & $\begin{array}{l}\text { AWD } \\
100 \text { mois }\end{array}$ \\
\hline 2 & 8 & Smoth & $\begin{array}{l}\text { Tumor } \\
\text { Well-limited }\end{array}$ & LSP & Pancreatic fistula & $\begin{array}{l}\text { AWD } \\
88 \text { months }\end{array}$ \\
\hline 3 & 15 & Smoth & $\begin{array}{l}\text { Tumor } \\
\text { well -limited }\end{array}$ & Whipple & Uneventfull & $\begin{array}{l}\text { VSR } \\
78 \text { months }\end{array}$ \\
\hline 4 & 8 & Smoth & $\begin{array}{l}\text { Tumor } \\
\text { well-limited }\end{array}$ & PG & Uneventfull & $\begin{array}{l}\text { AWD } \\
78 \text { months }\end{array}$ \\
\hline 5 & 10 & Smoth & $\begin{array}{l}\text { Tumor } \\
\text { well-limited }\end{array}$ & $\begin{array}{l}\text { Whipple + } \\
\text { ceasarean }\end{array}$ & Uneventfull & $\begin{array}{l}\text { AWD } \\
74 \text { months }\end{array}$ \\
\hline 6 & 15 & Smoth & $\begin{array}{l}\text { Tumor } \\
\text { well-limited with adhesion } \\
\text { to the colon and mesocolon }\end{array}$ & $\mathrm{LSP}+\mathrm{C}$ & Pulmonary embolism & $\begin{array}{l}\text { AWD } \\
\text { 48months }\end{array}$ \\
\hline 7 & 7 & Smoth & $\begin{array}{l}\text { Firm tumor and } \\
\text { well-limited }\end{array}$ & LP & Uneventfull & $\begin{array}{l}\text { AWD } \\
\text { 26months }\end{array}$ \\
\hline
\end{tabular}

LP: Left pancreatectomy - Left splenopancreatectomy - C: colectomy - AWD: alive without desease

Table $n^{\circ}$ 4: Histologic data.

\begin{tabular}{|l|l|l|l|l|l|l|l|}
\hline Variable & Case 1 & Case 2 & Case 3 & Case 4 & Case 5 & Case 6 & Case 7 \\
\hline Cells & $\begin{array}{l}\text { Uniforms } \\
\text { rounded }\end{array}$ & $\begin{array}{l}\text { Uniforms } \\
\text { rounded }\end{array}$ & Cubo-cylindrical & $\begin{array}{l}\text { Uniforms } \\
\text { rounded }\end{array}$ & $\begin{array}{l}\text { monomorphi } \\
\text { c }\end{array}$ & Rounded & monomorphic \\
\hline Architecture & $\begin{array}{l}\text { Pseudopapillary } \\
\text { and trabecular }\end{array}$ & $\begin{array}{l}\text { Papillary and } \\
\text { trabecular+ } \\
\text { pseudo-rosette }\end{array}$ & $\begin{array}{l}\text { Pseudo-papillary } \\
\text { rosettes } \\
\text { pseudo- } \\
\text { ependymal }\end{array}$ & $\begin{array}{l}\text { Pseudo- } \\
\text { papillary and } \\
\text { trabecular }\end{array}$ & $\begin{array}{l}\text { Pseuodo- } \\
\text { Papillary and } \\
\text { cribririforme }\end{array}$ & $\begin{array}{l}\text { Pseudo- } \\
\text { papillarye+ } \\
\text { rosette }\end{array}$ & $\begin{array}{l}\text { Papillary and } \\
\text { trabecular }\end{array}$ \\
\hline Nucleus & Rounded & Little & Rounded & Rounded & & Rounded & Rounded \\
\hline Mitosis & Few & Few & Absent & Few & Few & Few & Absent \\
\hline Nuclear atypia & - & - & Minimal & - & Minimal & Minimal & Absent \\
\hline Node & NX & N0 & N0 & NX & NX & N0 & NX \\
\hline Nervous sheaths & Absent & & Absent & Absent & & Absent & Absent \\
\hline Vascular emboli & Absent & Absent & Absent & Absent & Absent \\
\hline $\begin{array}{l}\text { Neighboring } \\
\text { pancreas }\end{array}$ & Healthy & Infiltrated & Healthy & Infiltrated & Healthy & Healthy & Healthy \\
\hline $\begin{array}{l}\text { Capsule } \\
\text { Intact }\end{array}$ & $\begin{array}{l}\text { Broken } \\
\text { (Fibrolamellar } \\
\text { defeated to } \\
\text { ruptured) }\end{array}$ & $\begin{array}{l}\text { Intact (Thick } \\
\text { librous and } \\
\text { laminated) }\end{array}$ & $\begin{array}{l}\text { Intact } \\
\text { (Fibrous and } \\
\text { thin) }\end{array}$ & $\begin{array}{l}\text { Broken } \\
\text { (Fibrous and } \\
\text { thick) }\end{array}$ & Intact & Intact & \\
\hline $\begin{array}{l}\text { Peritoneal } \\
\text { cytology }\end{array}$ & Suspecte & - & - & - & - & R0 & R0 \\
\hline
\end{tabular}

NX: Nodal status not unknown

Table $\mathbf{n}^{\circ}$ 5: Immunohistochemical analysis

\begin{tabular}{|c|c|c|c|c|c|c|c|}
\hline Parameter & Case 1 & Case 2 & Case 3 & Case 4 & Case 5 & Case 6 & Case 7 \\
\hline Progesterone receptors & + & NM & NM & NM & NM & + & + \\
\hline Oestrogen recepteors & NM & NM & NM & - & NM & NM & NM \\
\hline Ki67 & $10 \%$ & NM & NM & NM & $10 \%$ & NM & NM \\
\hline Vimentine & + & + & NM & + & + & + & + \\
\hline NSE & - & + & NM & NM & + & NM & NM \\
\hline Antisynaptophysine & NM & - & NM & NM & NM & NM & NM \\
\hline EMA & NM & NM & NM & - & $\mathrm{NN}$ & NM & NM \\
\hline Chromogranine & NM & NM & NM & $\mathrm{NM}$ & NM & - & - \\
\hline Beta cathenine & NM & NM & NM & NM & NM & + & NM \\
\hline AE1 & NM & NM & NM & NM & NM & + & NM \\
\hline AE3 & NM & NM & NM & NM & NM & + & NM \\
\hline Cytokeratine & NM & NM & NM & NM & - & NM & NM \\
\hline
\end{tabular}

NM: Not made. 


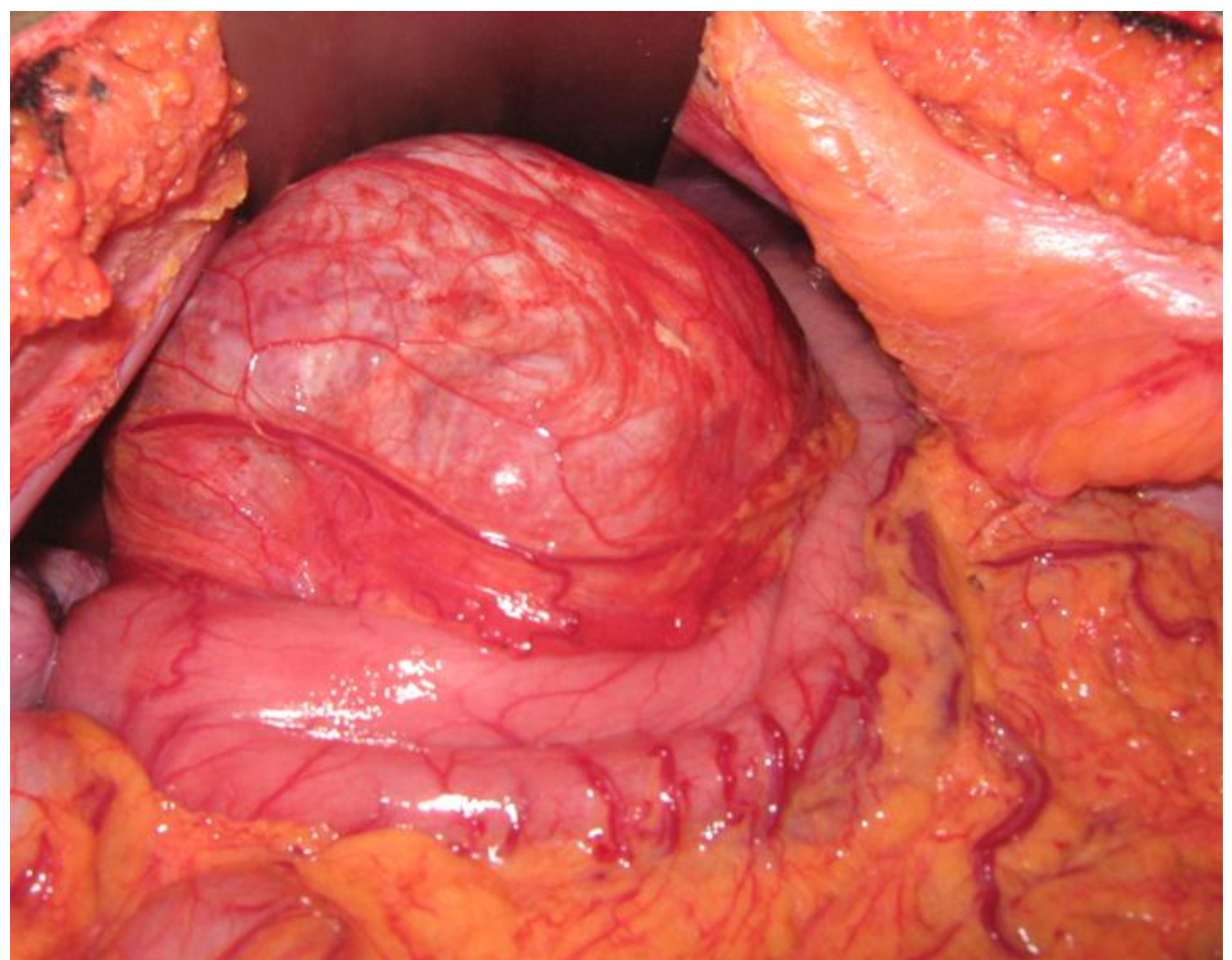

Figure $n^{\circ}$ 1: Pseudopapillary and solid tumor of pancreatic head Peroperative aspect (Case 3)

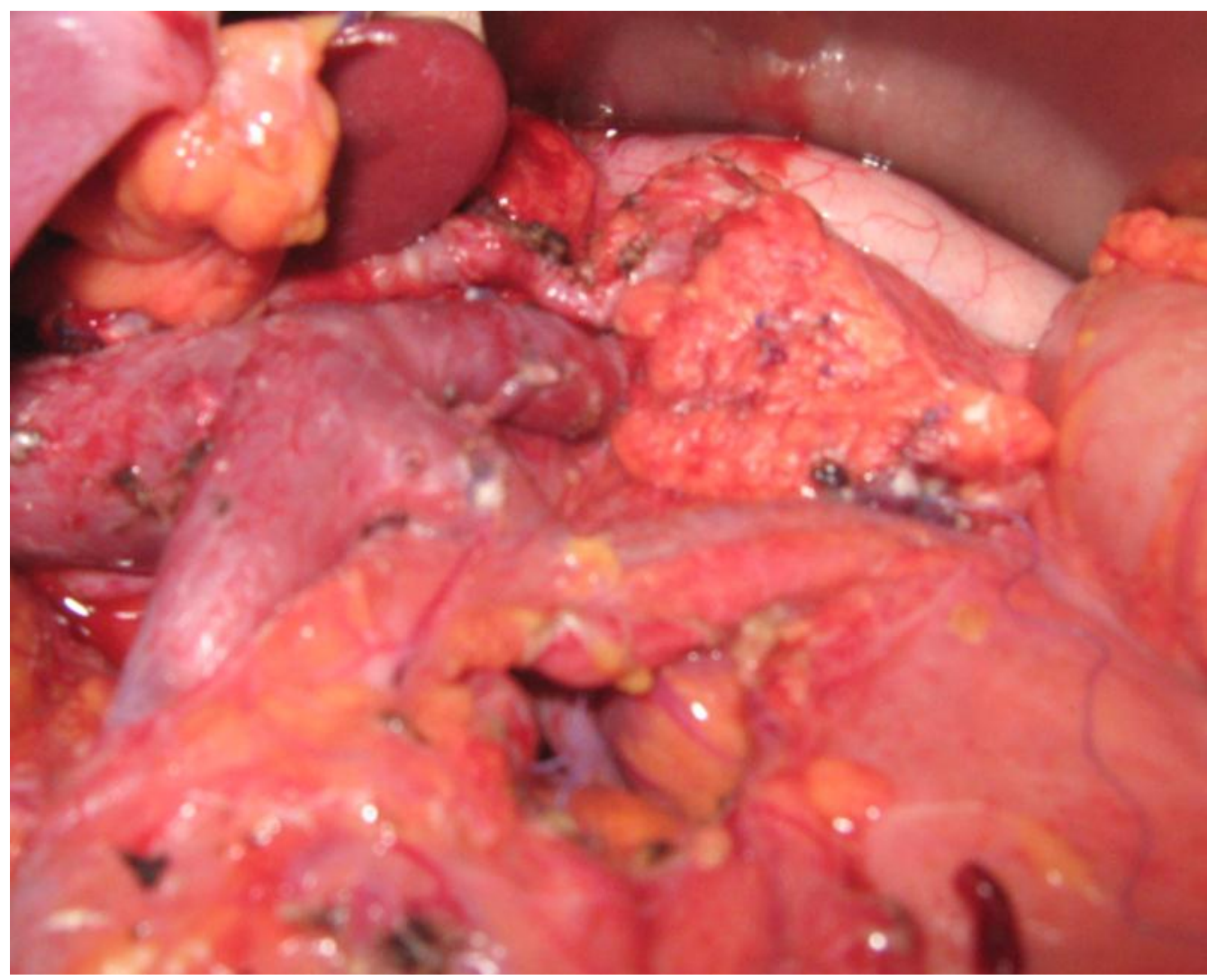

Figure $\mathbf{n}^{\circ}$ 2: Head of pancreas resected Peroperative aspect (Case 3)

\section{Discussion}

TSPPP is particular in that it occurs in young women around their thirties. They represent between 1.5 to $2.5 \%$ of all pancreatic tumors ${ }^{[4]}$. In our experience, this rate is $2.5 \%$. The average age of our series of 32.6 years is similar to that of the literature ${ }^{[5]}$. The signs most often encountered in patients are mild abdominal pain (often epigastric or left hypochondrium) and palpable mass (epigastric and left hypochondrium. This symptomatology is not specific or suggestive. We have to insist on the fact of the minimal intensity of the painful symptomatology of this disease. It is opposed to the pain of adenocarcinoma of the pancreas both for the cephalic localization (obstructive jaundice) and corporo-caudal (intense pains and characteristics of the pancreas). Other clinical signs can be reported as vomiting, anorexia, abdominal discomfort, nausea, jaundice, fever and weight loss ${ }^{[6]}$. The diagnosis of the 
tumor by chance or fortuitous way is not uncommon possibility. It was reported by all publications as in our series (cases 5 and 7) ${ }^{[7]}$. To be complete, PPSTP can be diagnosed at the stage of complications such as rupture ${ }^{[8]}$ and portal hypertension ${ }^{[9]}$. Modern imaging using computed tomography, MRI, transcutaneous ultrasound and endosonography. The elements that come back during these exams are the solid or tissue nature with areas of necrosis, hemorrhage, the presence of a capsule with a clear delimitation, the contrast enhancement for a tumor of large dimensions in a patient in good condition. This tumor must be retained if a full tissue mass found is well limited, large, encapsulated, solid and cystic with foci of hemorrhage, which are highlighted by a high signal in T1 accompanied by a slight and peripheral contrast at the injection of contrast medium ${ }^{[10]}$.

It must be said that MRI is superior to CT because it better shows the hemorrhagic components. A purely cystic aspect has been reported in the literature ${ }^{[11]}$. The images found in our series are identical to those in literature. On the biological level, note that markers such as Ca19.9 and ACE are of no use except to orient themselves towards another etiology (Frank and important elevation for example of Ca.19.9 and CEA in case of pancreatic adenocarcinoma). Intraoperatively, the tumor showed in the 7 patients the same aspect (well-limited tumor, with smooth surface, encapsulated). In only one patient, strong adhesion to the colon and mesocolon was noted. As with neuroendocrine tumors and stromal tumors, PPSTP increases in size without infiltrating the surrounding organs in the overwhelming majority of cases. For us, this is an element that should make them talk about preoperatively and intraoperatively. In rare cases, venous infiltration has been reported in the literature ${ }^{[12]}$, such as the presence of liver metastases ${ }^{[13]}$ or peritoneal carcinosis ${ }^{[14]}$. Histological analysis of the operating room showed in our series the absence of perinervous sheathing, vascular emboli and lymph node infiltration. This is what is reported in the overwhelming majority of cases in the literature. In fact, Siva $\mathrm{P}$ et al ${ }^{[15]}$ propose the following elements as aggressive : T3 or more, perinervous sheaths, vascular emboli, lymph node infiltration and metastatic development. It is important that the question of malignancy is asked at the time of diagnosis of PPSTP to adapt the surgical procedure because it must be the most conservative type of enucleation or pancreatic resection without splenectomy and without lymphadenectomy, especially for tumors located at left.

This surgical resection is and must be of the R0 type (which is possible for the majority of cases). In our series, this was possible in the seven patients, even if the neighboring pancreas was infiltrated in two of them. Our patients are alive without recurrence with an average survival of 70,3months (26 - 100 months) and 64\% survival at 5 years. A recurrence such as liver metastases, peritoneal carcinosis, or locoregional may occur ${ }^{[16]}$. Even in recurrence, surgery with curative resection must be attempted because survival after new R0 type resection is interesting ${ }^{[17]}$. Conclusion: The PPSTP is an entity to know and recognize. It should be mentioned when a young woman around the age of 30 has a mixed and well-limited pancreatic tumor process. This process can have an important dimension, is palpable, and does not cause the complications or the usual symptomatology of pancreatic cancer (jaundice and intense pain). Modern imaging with transcutaneous ultrasound, CT scan, MRI can evoke the diagnosis. Surgical resection type R0 is the treatment of choice. This surgery should be as far as possible a limited pancreatic resection, without sacrifice of the spleen and without lymphadenectomy for the tumors located on the left. For cephalic localization, Whipple resection is the method of choice when the tumor is large, but limited surgery may be attempted for tumors of $30 \mathrm{~mm}$ and less.

\section{References}

[1] Frantz VK. Papillary tumors of the pancreas: Benign or malignant? Tumors of the pancreas. In: Atlas of Tumor Pathology, Section 7, Fascicles 27 and 28.Washington, DC, USA: Armed Forces Institute of Pathology, 1959:32-3

[2] Kloppel G, Solcia E, Longnecker DS, Capella C, Sobin LH. Histological typing of tumors of the exocrine pancreas. In: World Health Organisation. International histological classification of tumors. 2nd ed. Berlin Heidelberg New York: Springer, 1996: 120-128.

[3] X. G. Wang, Q.F. Ni, J.G. Fei, Z.X. Zhong, P.F.Yu. Clinicopathologic features and surgical outcome of solid pseudopapillary tumor of the pancreas: analysis of 17 cases. World Journal of Surgical Oncology 2013, 11:38.

[4] N. Guo,Q.B. Zhou, R.F. Chen, S.Q. Zou, Z.H. Li,Q.Lin, J.Wang, J.S. Chen. Diagnosis and surgical treatment of solid pseudopapillary neoplasm of the pancreas: analysis of 24 cases. J Can Chir 2011; 54:368-374.

[5] T. B. Patil, S. V. Shrikhande, H. A. Kanhere, R. R. Saoji, M. R. Ramadwar, P. J. Shuklah.. Solid pseudopapillary neoplasm of the pancreas: a single institution experience of 14 cases. HPB, 2006; 8: 148_/150.

[6] Peng-Fei Yu, Zhen-Hua Hu, Xin-Bao Wang, Jian-Min Guo, Xiang-Dong Cheng, Yun-Li Zhang, Qi Xu. Solid pseudopapillary tumor of the pancreas: A review of 553 cases in Chinese literature World J Gastroenterol 2010; 16: 1209-1214.

[7] Yagcı, S. Yakan, A.Coskun, N.Erkan, M. Yıldırım, E.Yalc1n, H.Postac1. Diagnosis and treatment of solid pseudopapillary tumor of the pancreas: experience of one single institution from Turkey. World Journal of Surgical Oncology 2013, 11:308.

[8] Takamatsu S., Hiroto Nagano, Shunroh Ohtsukasa, Yasuyuki Kawachi, and Hiroshi Maruyama. A Case of Spontaneous Ruptured Solid Pseudopapillary Tumor of Pancreas Resected by Laparoscopic Surgery. Case Reports in Medicine, Volume 2013,

[9] Wani NA, Lone TK, Shah AI, Khan AQ, Malik RA. Malignant solid pseudopapillary tumor of pancreas causing sinistral portal hypertension. Indian J Pathol Microbiol. 2011; 54:152-155.

[10] Herrmann KA, Helmberger T, Bruns C, Reiser MF, Zech CJ. Solid pseudopapillary pancreas tumors--often neglected. Radiologe. 2008; 48:764-769.

[11] K. Y. Paik, S. H. Choi, J. S. Heo, D. W. Choi. Solid tumors of the pancreas can put on a mask through cystic change. World Journal of Surgical Oncology 2011, 9:79].

[12] Sperti Volmer Jr C.M, Dixon E., Grant DR. Management of solid pseudopapillary tumor of pancreas with hepatic metastasis. HPB; 2003; 5: 264-267

[13] Volmer CM Jr, Dixon E, Grant DR. Management of pseuodpapillary tumor of pancreas with metastases. HPB 2005, 5:264-364

[14] Levy P, Bougaran J, Gayet B. TSPPP et survenue rare de carcinose péritonéale. Diffuse peritoneal carcinosis of pseudo-papillary and solid tumor of the pancreas. Role of abdominal injury]. Gastroenterol Clin Biol. 1997; 21:789-793. 
[15] Siva P. Raman, Satomi Kawamoto, Joanna K. Law, Amanda Blackford, Anne Marie Lennon, Christopher L. Wolfgang, Ralph H. Hruban, John L. Cameron, and Elliot K. Fishman. Institutional Experience With Solid Pseudopapillary Neoplasms: Focus on Computed Tomography, Magnetic Resonance Imaging, Conventional Ultrasound, Endoscopic Ultrasound, and Predictors of Aggressive Histology. J Comput Assist Tomogr. 2013; 37(5): 824-833.
[16] Hao E.II U., H. Kyung Hwang, D.S Yoon, W. J. Lee, C.M. Kang, Aggressiveness of solid pseudopapillary neoplasm of the pancreas. A literature review and metaanalysis. Medicine; 2018 97:49

[17] P. K. Sharma, S. Mehrotra, A.L. Gleisner, R.D. Schulick, M. D. McCarter. Recurrent Solid Pseudopapillary Neoplasm of Pancreas: Case Report and Review of Literature. Journal of Pancreatic Cancer ; 2018 ; 4.1 